\title{
Evaluation of Bentonite Mixed Indigenous Clays for Development of Clay Liners
}

\author{
Muhammad Israil a, Muhammad Ashraf b, Muhammad Fahim ${ }^{\text {a* }}$, Rashid Rehan ${ }^{\text {a }}$, \\ Sajjad Wali Khan ${ }^{\text {a }}$, Shabir Hussain ${ }^{\mathrm{a}}$ \\ ${ }^{a}$ Civil Engineering Department, University of Engineering and Technology, Peshawar 25000, Pakistan. \\ ${ }^{b}$ Department of Civil Engineering, Ghulam Ishaq Khan Institute of Engineering Sciences and Technology, Topi 23460, Pakistan
}

Received 15 June 2020; Accepted 28 September 2020

\begin{abstract}
This study presents experimental investigation of indigenous clays mixed with Bentonite to assess their suitability in potential use as clay liners. Soil samples with $0,4,8$, and $12 \%$ Bentonite content from three different sites in Peshawar region were tested for various geotechnical properties. Grain size distribution, specific gravity, Atterberg limits and free swell were found through laboratory tests using appropriate ASTM procedures. Maximum dry density and optimum moisture content were calculated using Atterberg limits in available relationships. Finally, one dimensional consolidation tests were conducted to find relevant parameters for calculating hydraulic conductivity. A decrease in specific gravity, increase in free swell, and in optimum moisture content, decline in maximum dry density and hydraulic conductivity was observed with increase in Bentonite content across all three soil samples. During free swell, the soil clusters become larger leading to formation of floccules resulting in the narrowing of inter-particle space and thus blocking of permeable paths. It is concluded that $8 \%$ Bentonite content by weight yields a suitable mixture for a clay liner that has hydraulic conductivity in the range of recommended limits.
\end{abstract}

Keywords: Bentonite; Clay Liners; Hydraulic Conductivity; Atterberg Limits.

\section{Introduction}

The safe and efficient disposal of solid waste is indispensable as it poses a hazard to the environment, and is an emergent problem in developing countries. Environmental degradation is mainly associated with the malpractices of solid waste dumping that has become an emerging issue for many urban centres around the world. The phenomenon of urbanization influx coupled with escalated population growth in developing countries has exacerbated the situation. Pakistan is no exception where solid waste is a growing problem. The absence of engineered methods of disposal and open dump approach is creating major environmental and social issues within most of the cities. Solid waste is disposed haphazardly in open dumps and they are subsequently subjected to burning. Growth rate of waste generation in Pakistan is 2.4 percent per year and solid waste production lies in the range of 0.283 to $0.612 \mathrm{~kg}(0.624$ to 1.349 lbs.) per person per day [1]. At present, only 50\% of waste quantities generated in Pakistan is collected by government owned and privately operated services, though, for cities to be comparatively clean at least $75 \%$ of these quantities should be disposed properly [2].

\footnotetext{
* Corresponding author: drmfahim@uetpeshawar.edu.pk
} 
A waste dumping site has long been used as engineered containment systems to mitigate the environmental footprint of disposed waste [3]. However, it is observed that multifaceted pollution problems spread in close vicinity of waste dumping yards. Slush wastes and rainwater infiltrates through waste layers and generates leachate that ultimately contaminates the ground water. The leachate of hazardous waste may cause detrimental effect on groundwater leading to soil \& water contamination [4]. Similarly, vast waste dump yards provide free room to multiple epidemics that include diarrhea, malaria and dysentery that has catastrophic effects on environment and public health. It is well established fact that a large number of water borne diseases are resulted due to poor collection and disposal practices of solid waste. Rapid economic development, improved living standards and urbanization have increased in accumulative quantities of hazardous waste produced by industries. Malpractices of disposal of solid waste has further aggravated the situation in many parts of the world.

Fortunately, contamination of ground by solid waste can be minimized by simple means with the provision of proper landfills, which incorporate clay liner that acts as a barrier and prevents leachate to reach clean and hygienic sub-surface water. Compacted clay liners (CCLs) and geosynthetic clay liners (GCL) are barrier systems in landfill design as their hydraulic conductivity is very low. Laboratory and field investigations have shown that the application of either the CCL or GCL while underlain by a geomembrane could effectively prevent the advection and diffusion of the contaminants into the surrounding environment $[5,6]$. CCL is composed of thick compacted layers of soil having thickness of 0.80 to $1.0 \mathrm{~m}$. The efficiency of landfills largely depends on the hydraulic performance of clay liners. Environmental regulatory authorities require hydraulic conductivity/permeability of clay liners to be less than a specified maximum value. For example, the maximum limit in the USA is $1 \times 10^{-9} \mathrm{~m} / \mathrm{s}\left(3.28 \times 10^{-9} \mathrm{ft} / \mathrm{s}\right)$ and $1 \times 10^{-8} \mathrm{~m} / \mathrm{s}$ $\left(3.28 \times 10^{-8} \mathrm{ft} / \mathrm{s}\right)$ in Turkey [7]. Development of simple landfill facilities utilizing locally available materials to suit landfill liner requirements is the most economical and timely solution to this problem.

In recent past, guidelines have been compiled for selecting suitable soil properties and compaction procedures that are likely to result in low hydraulic conductivity [8]. These guidelines are normally based on experience and generally include adequate ranges or minimum values for properties that describe composition of soil (e.g., particle-size distribution, Atterberg limits, swelling indices) and recommendations for selection of compaction criteria (i.e., control of water content and dry unit weight) and compaction machinery. Extensive research is also being conducted to develop numerical models for accurate determination of various soil parameters [9]. This article describes these parameters for bentonite mixed clays for the development of clay liners. The use of bentonite in clay liners is discussed first, followed by the methodology adopted in the study. The results and discussion section presents the tests conducted. Finally, conclusions derived from the study are discussed.

\subsection{Use of Bentonite in Clay Liners}

Bentonite is considered as a potential buffer material in landfills due to its hydraulic conductivity, and self-healing properties [10]. It is widely reported as suitable material used in partial replacement of cement and low cost construction materials $[11,12]$. Bentonite swell up to 15 times its original volume and it rapidly hydrates when exposed to liquids and attracts positively charged water particles. Researchers explained that a hole up to $75 \mathrm{~mm}$ in diameter will heal itself, allowing the geosynthetic clay liner to maintain the properties that make it an efficient barrier system [13]. Bentonite mixtures are generally used as geoenvironmental barriers to prohibit the movement of fluid from waste dumping facilities [14]. Swelling mechanism in Bentonite aids in the reliability of CCLs as well as GCLs. With an increase in swelling capability, there exists an increase in self-healing capability [15].

Because of low permeability and high swelling ability of Bentonite, its combination with CCL could further accentuate in lowering the hydraulic conductivity and may have potential of excellent barrier. Reduction in the hydraulic conductivity of soils is achieved with addition of Bentonite that modifies soil composition and can be used as replacement to accomplish requirements of CCL. Cho et al., [16] studied the hydraulic conductivity of compacted blended mixtures for a liner material in landfill facilities and concluded that that MDD decreases whereas OMC increases with the percentage increase of Bentonite. A study by O' Sullivan and Quigley concluded that clay liner tested obtained minimum permeability $\left(1 \times 10^{-9} \mathrm{~m} / \mathrm{s}\right.$ or $\left.3.28 \times 10^{-9} \mathrm{ft} / \mathrm{s}\right)$ when the moisture content dropped as much as $3 \%$ below optimum [17]. The same study found that soil is unlikely to achieve adequately low permeability if the plasticity index is less than $10 \%$. Similarly, the Atterberg limits (LL and the PI) are mostly affected by the ability of clay minerals to interact with water [18] and the hydraulic conductivity decreases with the increase of liquid limit and plasticity index [7]. With the percentage addition of Bentonite to the original soil, the liner requirement with respect to hydraulic conductivity can be achieved and makes the liner practically impervious [8, 19, 20].

Literature on the potential use of CCLs is scanty available in Pakistan, especially utilizing Bentonite. The research under consideration is therefore designed to assess and evaluate suitable partial substitution of Bentonite with indigenous clays in Peshawar region for the development of clay liners. 


\section{Research Methodology}

Soil samples collected from three locations (Figure 1), namely, Maryam Zai (M-Zai), Saran Mara (S-Mara), and Shamshatoo Camp (S-Camp) in Peshawar region of Pakistan were investigated. Four samples of each soil with 0, 4, 8 and $12 \%$ Bentonite content were tested for various parameters to check their suitability as clay lining material. Tests conducted include grain size distribution, specific gravity, Atterberg limits, free swell, consolidation, and hydraulic conductivity. The research methodology is presented in the flowchart shown in Figure 2.

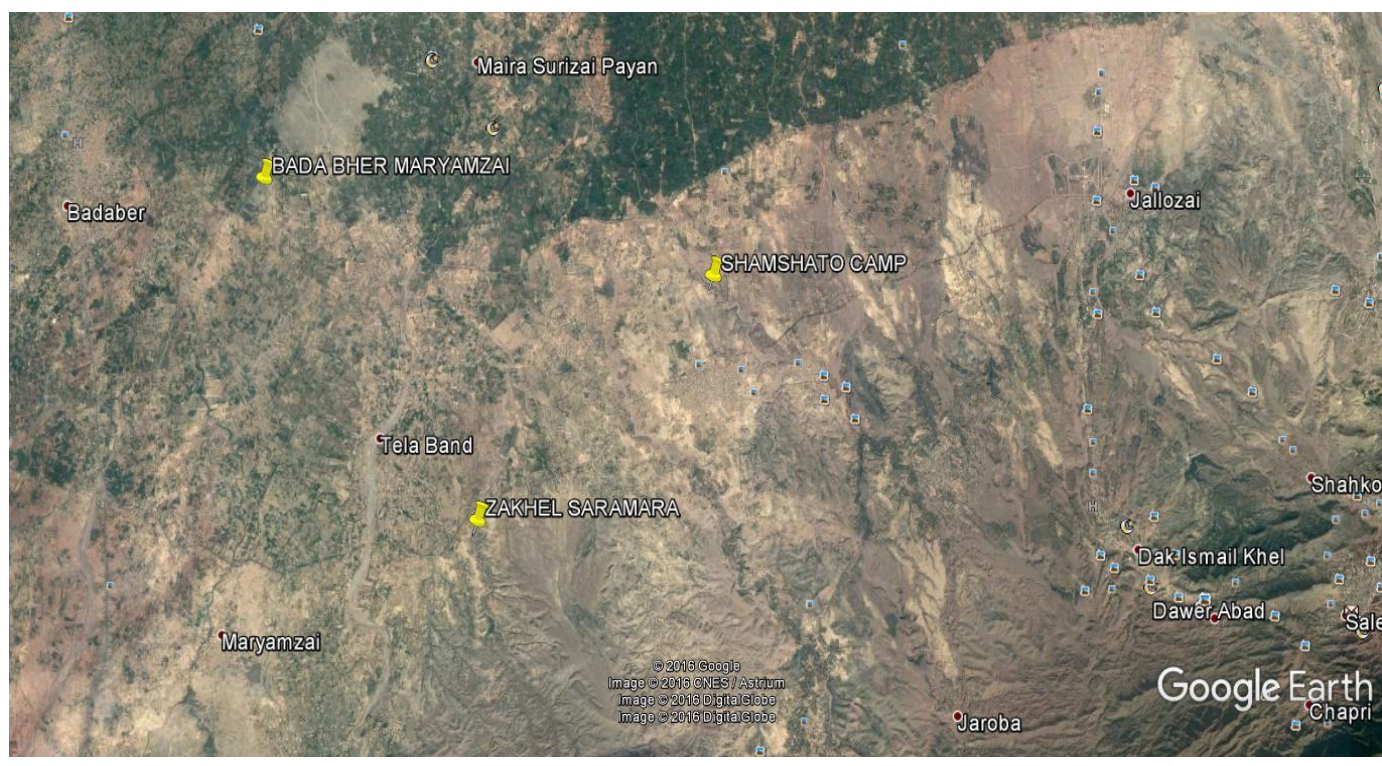

Figure 1. Sites of collected samples

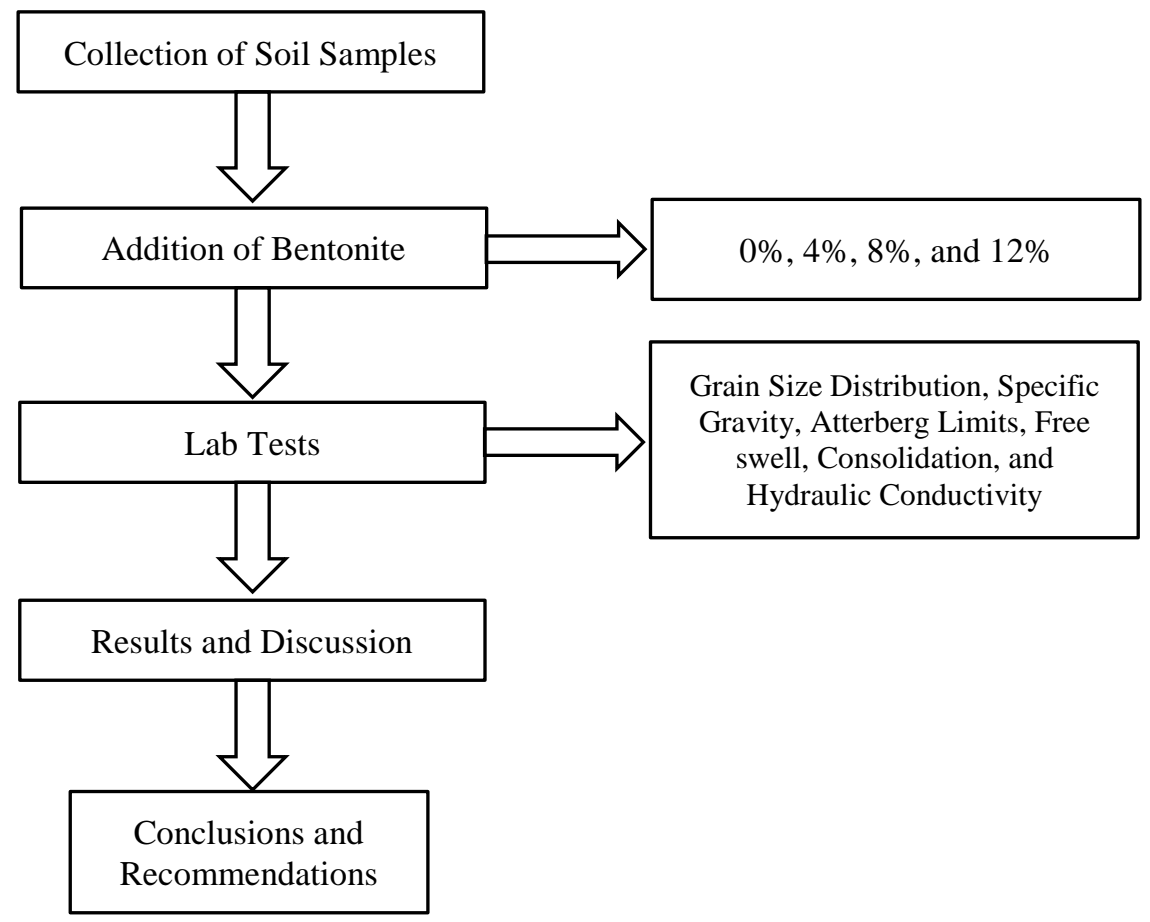

Figure 2. Steps followed in the research

\section{Results and Discussion}

\subsection{Grain Size Distribution and Specific Gravity}

Permeability of soils depends greatly on the gradation curve obtained from particle size analysis. In order to attain hydraulic conductivity in the recommended range of less than $1 \times 10^{-8} \mathrm{~m} / \mathrm{s}\left(3.28 \times 10^{-8} \mathrm{ft} / \mathrm{s}\right)$, the fine fraction should be equal or greater than $30 \%$ whereas clay fraction should be greater than $15 \%$. The soil gradation for particles retained on sieve No. $200(>75 \mu \mathrm{m})$ was calculated using sieve analysis whereas the soil particles passing $75 \mu \mathrm{m}$ sieve was 
evaluated by hydrometer analysis following ASTM D7928-17. The results are shown in Figure 3. According to Head [21], hydrometer analysis is carried out when more than $10 \%$ of the sample pass the $75 \mu \mathrm{m}$ test sieve. In current research work, all three soils were observed to have greater than $10 \%$ of soil sample passing sieve \#200. For this purpose, hydrometer of type $152(\mathrm{H})$ was used.

All soil samples contained clay and silt fraction of $53 \%$, thus fulfilling the criteria of clay liners as the amount of percent finer is more than $30 \%$. The results of hydrometer analysis indicate a similar trend across all samples and the amount of clay fraction also remained same showing equivalent gradation.

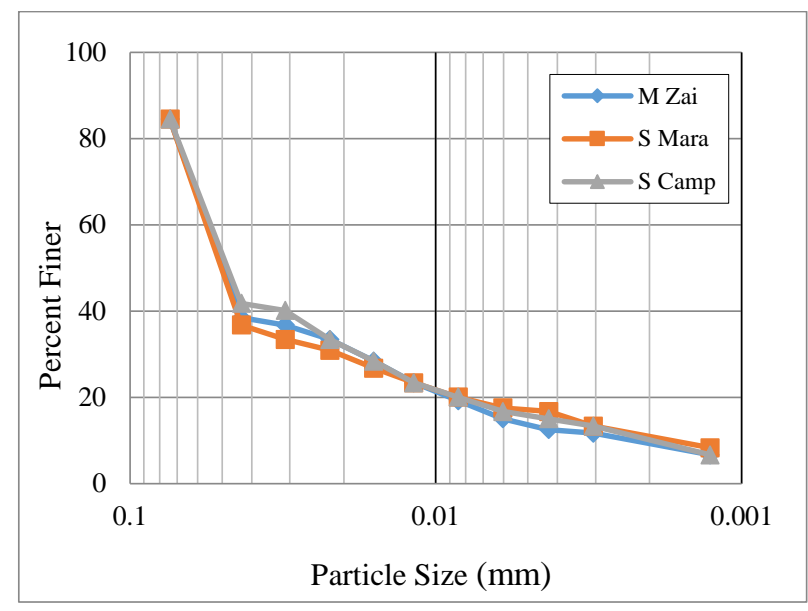

Figure 3. Particle size distribution

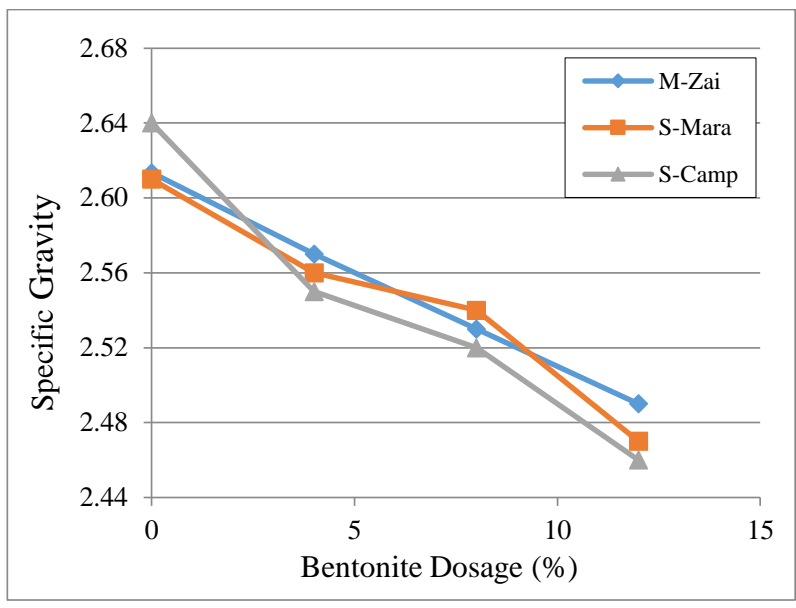

Figure 4. Variation in specific gravity

Specific gravity is helpful in finding the unit weight of the soil under different conditions, determination of particle size by hydrometer analysis, and degree of saturation of soil in moist state. The specific gravity of soil samples were determined as per guidelines of ASTM D854-14. A decrease in the specific gravity was observed with increase in the Bentonite dosage as shown in Figure 4. This is mainly attributed due to the higher clay content. The specific gravity of soil-bentonite mixtures ranges from 2.47-2.67 and can be classified as inorganic clays.

\subsection{Atterberg Limits}

Atterberg limits were determined for air-dried samples according to ASTM-D4318-17. The portions of the samples passing No. $40(0.425 \mathrm{~mm})$ sieve were obtained for carrying out liquid limit (LL) and plastic limit (PL) tests (Figures 5 and 6). During testing, room temperature of $21-24{ }^{\circ} \mathrm{C}$ was maintained. Figure 7 shows the changes in LL with increase in Bentonite dosage. The liquid limit increases with increase in Bentonite up to $8 \%$ for all samples. However, LL of both S-Maira and S-Camp soils decreased with increase in bentonite dosage beyond $8 \%$ showing lower capacity of water retention.

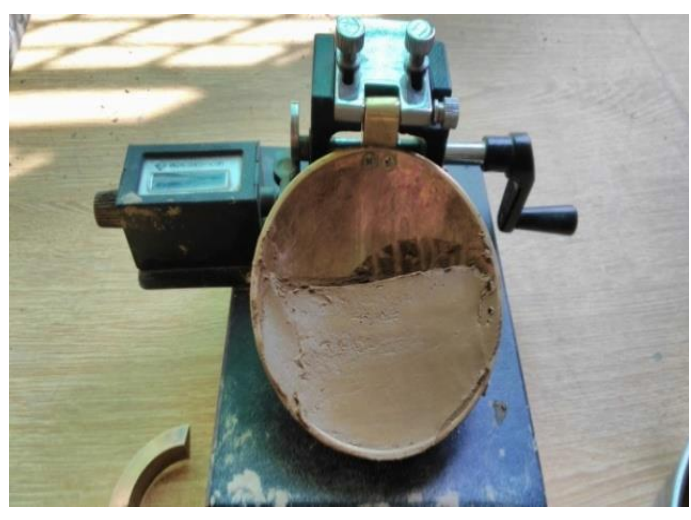

Figure 5. Liquid limit test

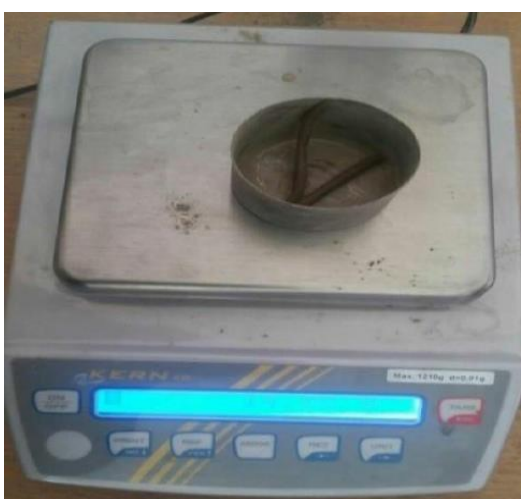

Figure 6. Plastic limit test

Figure 8 shows the changes in PL with increase in Bentonite dosage. An increasing trend was observed in plastic limit when more percentage of Bentonite was introduced in M-Zai and S-Maira soil whereas decreasing trend can be seen in the case of S-Camp soil. Change in consistency limits of mixtures may be due to mixture type [22] and the relative amount of clay mineral present in the soil mixtures [23]. 


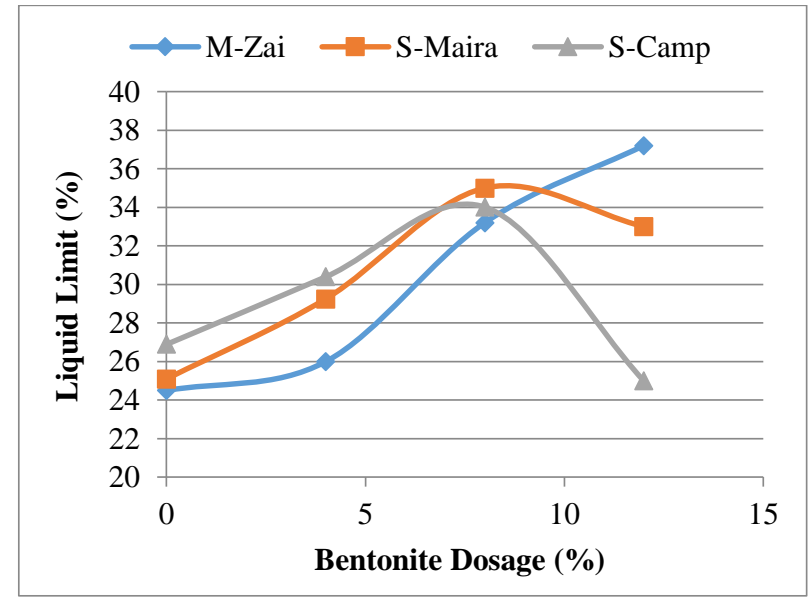

Figure 7. Variation in liquid limit

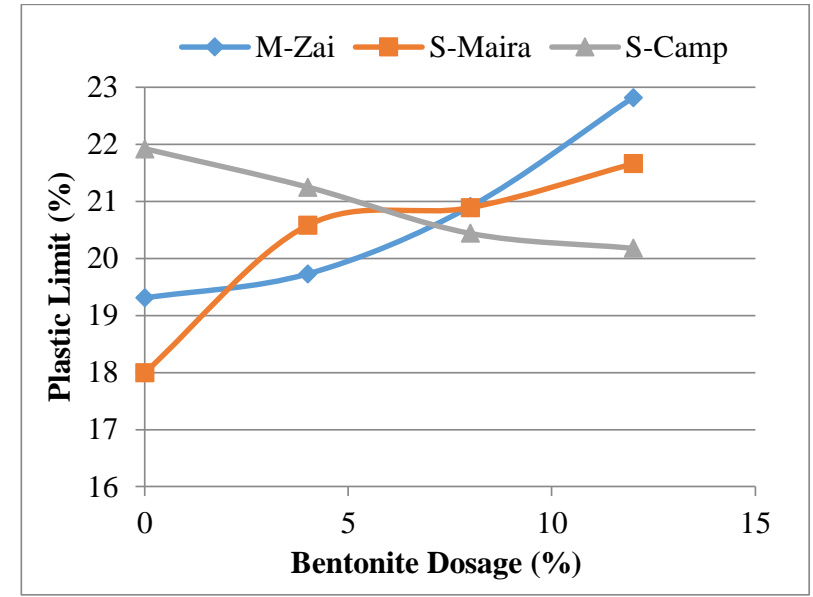

Figure 8. Variation in plastic limit

The plasticity index (PI) of all samples were also calculated and the results are shown in Figure 9. Soils with plasticity index greater than $10 \%$ has been widely used successfully to construct soil liners. All three soils have PI greater than $10 \%$ with Bentonite substitution of $8 \%$. Increase in PI of clayey soils with Bentonite has also been reported previously $[8,19,20]$. All plain samples lied in low plasticity range whereas soils having 8 and $12 \%$ Bentonite content lie in medium and high plasticity ranges respectively.

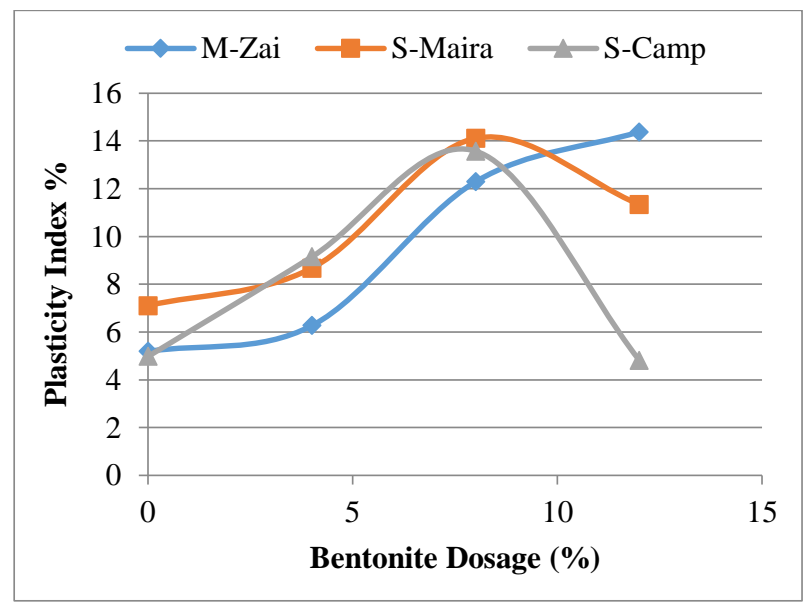

Figure 9. Variation in plasticity index

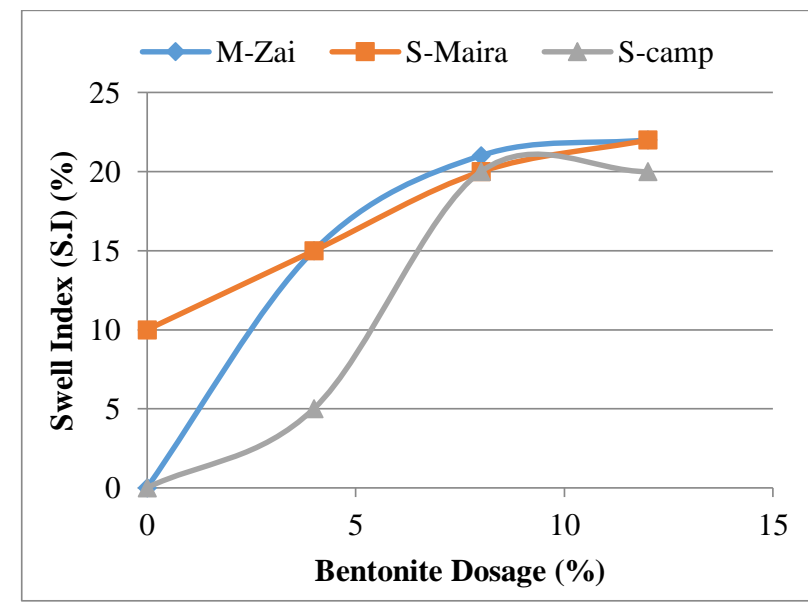

Figure 10. Variation in free swell

\subsection{Free Swell Test}

Free swell is the increase in volume of unconstrained soil on submergence in water. Free swell of the soil samples was determined as per ASTM D5890-11 and the results are shown in Figure 10. It is found that free swell increases with the increase in content of Bentonite. The free swell of all soil samples is more than $20 \%$ above $8 \%$ Bentonite substitution; however only a small increase in free swell is observed beyond $8 \%$ substitution. The weight volume relationship parameters, saturation ratio, specific gravity, and natural unit weight along with relative amount of clay sized particles and their mineralogy are physically related to free swell of the soil. The soil clusters become larger during free swell leading to formation of floccules resulting in the narrowing of inter-particle space and thus blocking of permeable paths [24].

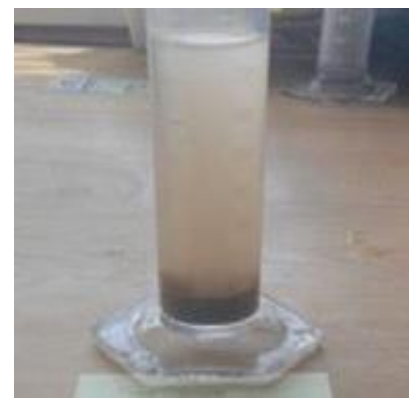

Figure 11. Free swell test using $100 \mathrm{ml}$ graduated cylinder 


\subsection{Moisture-density Relationships}

The maximum dry density (MDD) and optimum moisture content (OMC) are determined using the following relations and the results are shown in Figures 12 and 13.

$\gamma_{d(\max )}=20.48-0.13 L L+0.15 P I$

$O M C=6.77+0.43 L L-0.21 P I$

It is found that with the percentage addition of Bentonite, MDD decreases and OMC increases. There is a smooth draw down in MDD across M-Zai, S-Mara and S-Camp soil up to $8 \%$ addition of Bentonite whereas a slight increase in MDD is noticed in S-Mara and S-Camp soil with $12 \%$ addition of Bentonite content. It is due to the reason that Bentonite has less density as compared to soil. As Bentonite is very fine in nature thus percentage addition of Bentonite leads to the decrease in MDD and greater surface area of Bentonite requiring more water to saturate causes an increase in $\mathrm{OMC}$.

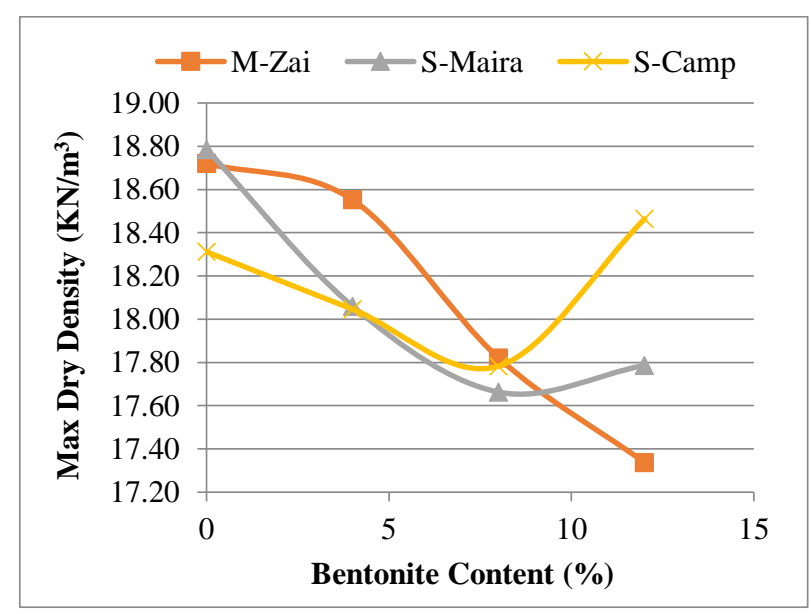

Figure 12. Variation in maximum dry density

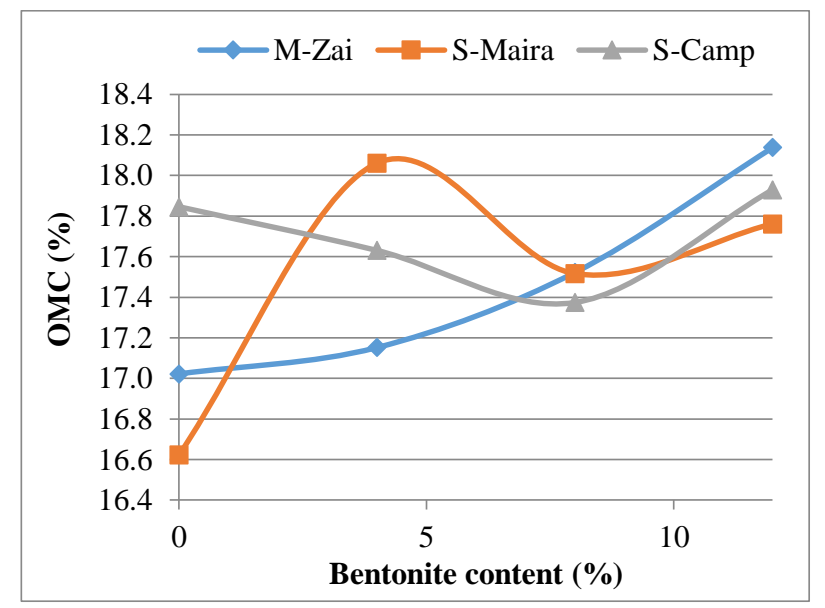

Figure 13. Variation in optimum moisture content

The decrease in dry unit weight with percentage increase in bentonite content may be associated with high swelling characteristics of bentonite clay that forms a thixotropic gel called diffused double layer around the soil particles. Due to the formation of this layer the overall effective size of soil particles increases, as a result void volume increases and dry unit weight deceases.

Accurate determination of moisture content is of paramount importance for hydraulic conductivity. It was measured by weighing specimens before and after oven drying for 24 hours at a temperature of $105{ }^{\circ} \mathrm{C}$.

\subsection{Determination of Hydraulic Conductivity (k)}

The coefficient of permeability $(\mathrm{k})$ was measured from consolidation tests for all specimens using Equation 3 [25].

$k=c_{v} m_{v} \gamma_{w}$

Where $c_{v}$ is coefficient of consolidation, $m_{v}$ is volume coefficient of compressibility, and $\gamma_{w}$ is unit weight of water. The coefficient of consolidation is calculated using square root of time method which results in Equation 4 [25].

$c_{v}=\frac{0.848 H^{2}}{t_{90}}$

In Equation 4, $H$ is the height of the specimen and $t_{90}$ is the time required for $90 \%$ of consolidation. The volume coefficient of compressibility is calculated suing Equation 5 [25].

$m_{v}=\frac{\Delta e}{\Delta \sigma\left(1+e_{o}\right)}$

In Equation 5, $\Delta e$ is change in void ratio for $\Delta \sigma$ incremental pressure applied and $e_{o}$ is the initial void ratio. One dimensional conventional Oedometer tests were performed using ASTM-D2435-11 on samples prepared based on the values of OMC and MDD. Different stress increments of 2.40, 4.80, 9.61, and $19.22 \mathrm{lbs} .(1.09,2.18,4.36$ and $8.72 \mathrm{~kg}$ ) were applied on each specimen in the Oedometer for a period of 24 hours in order to develop the voids ratio (e) vs. $\log (\sigma)$ graph. Dial gauge readings were noted at regular intervals during loading of the specimens. 


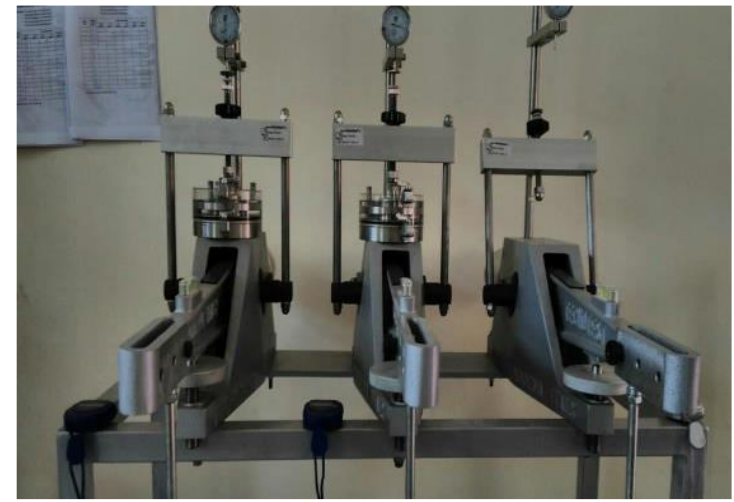

Figure 14. Oedometer for consolidation test

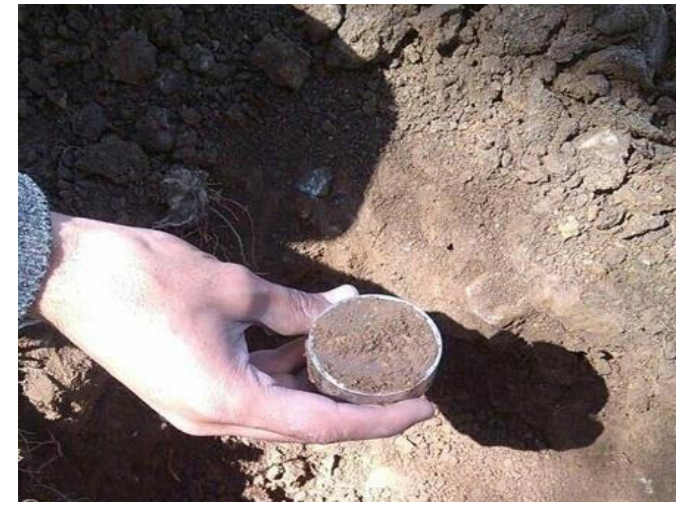

Figure 15. Sample for consolidation test

Table 1 summarizes the results obtained for specimens. Hydraulic conductivity decreases with the decrease in dry unit weight and increase in moisture content. It complies with previous studies [26] where OMC increases with the decrease of MDD. The finding in this study showed similar trend where the soil specimen having less dry unit weight and higher optimum moisture content results in a lower hydraulic conductivity.

Table 1. K values of soils corresponding to MDD and OMC

\begin{tabular}{cccccc}
\hline \multirow{2}{*}{ Sample } & Properties & \multicolumn{4}{c}{ Bentonite Dosage (\%) } \\
\cline { 3 - 6 } & & $\mathbf{0}$ & $\mathbf{4}$ & $\mathbf{8}$ & $\mathbf{1 2}$ \\
\hline \multirow{2}{*}{ M-Zai } & $\mathrm{MDD}, \mathrm{kN} / \mathrm{m}^{3}\left(\mathrm{lb} / \mathrm{ft}^{3}\right)$ & $18.72(119.17)$ & $18.55(118.09)$ & $17.82(113.44)$ & $17.34(110.38)$ \\
& $\mathrm{OMC}(\%)$ & 19.70 & 19.95 & 21.35 & 21.84 \\
& $\mathrm{~K}, \mathrm{~m} / \mathrm{sec}(\mathrm{ft} / \mathrm{sec})$ & $1.06 \mathrm{E}-8(3.48 \mathrm{E}-8)$ & $9.25 \mathrm{E}-9(3.03 \mathrm{E}-8)$ & $8.31 \mathrm{E}-9(2.73 \mathrm{E}-8)$ & $8.38 \mathrm{E}-9(2.75 \mathrm{E}-8)$ \\
\hline \multirow{2}{*}{ S-Maira } & $\mathrm{MDD}, \mathrm{kN} / \mathrm{m}^{3}\left(\mathrm{lb} / \mathrm{ft}^{3}\right)$ & $18.78(119.55)$ & $18.06(114.97)$ & $17.66(112.42)$ & $17.79(113.25)$ \\
& $\mathrm{OMC}(\%)$ & 20.14 & 20.04 & 21.78 & 21.13 \\
& $\mathrm{~K}, \mathrm{~m} / \mathrm{sec}(\mathrm{ft} / \mathrm{sec})$ & $8.31 \mathrm{E}-9(2.73 \mathrm{E}-8)$ & $8.0 \mathrm{E}-9(2.62 \mathrm{E}-8)$ & $7.9 \mathrm{E}-9(2.59 \mathrm{E}-8)$ & $7.81 \mathrm{E}-9(2.56 \mathrm{E}-8)$ \\
\hline \multirow{2}{*}{ S-Camp } & $\mathrm{MDD}, \mathrm{kN} / \mathrm{m}^{3}\left(\mathrm{lb} / \mathrm{ft}^{3}\right)$ & $18.31(116.56)$ & $18.05(114.90)$ & $17.78(113.19)$ & $17.46(111.15)$ \\
& $\mathrm{OMC}(\%)$ & 19.65 & 20.62 & 21.65 & 19.15 \\
& $\mathrm{~K}, \mathrm{~m} / \mathrm{sec}(\mathrm{ft} / \mathrm{sec})$ & $8.94 \mathrm{E}-9(2.93 \mathrm{E}-8)$ & $8.36 \mathrm{E}-9(2.74 \mathrm{E}-8)$ & $8.05 \mathrm{E}-9(2.64 \mathrm{E}-8)$ & $7.98 \mathrm{E}-9(2.62 \mathrm{E}-8)$ \\
\hline
\end{tabular}

Figure 14 shows variation of hydraulic conductivity with percentage of Bentonite added in soil samples. Hydraulic conductivity decreases with increasing percentage of Bentonite. The hydraulic conductivity decreases with increasing Bentonite content. However, the rate of decrease reduces beyond $8 \%$ addition of Bentonite. The decreasing trend depends upon percentage increase of fine particles as well as compaction density of soil-Bentonite mixtures. At lower compaction density the degree of decrease in hydraulic conductivity is more remarkable. With the increase of Bentonite, hydraulic conductivity decreases and mainly associated with reduction of diffused double layer thickness surrounding the clay particles and decreases the hydraulic conductivity. Comparing the calculated values of hydraulic conductivity with recommended limits, the specimens are most suited as clay lining material with $8 \%$ addition of Bentonite [7].

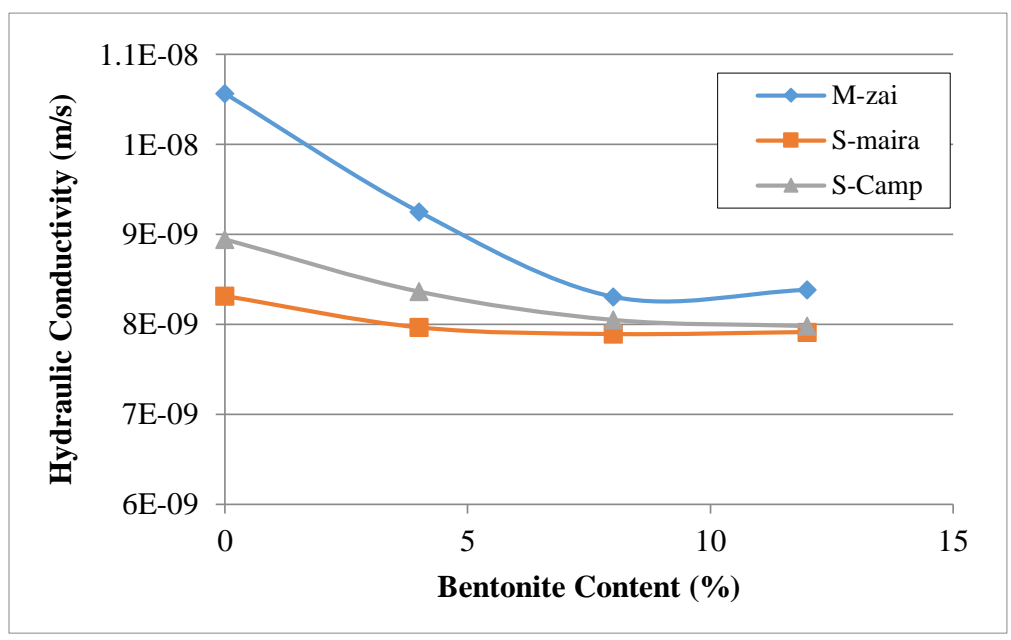

Figure 16. Variation in hydraulic conductivity 


\section{Conclusion}

It is concluded that all three soils fulfil the criteria of clay liners as the amount of percent finer is more than $30 \%$. The specific gravity decreases with an increase in Bentonite content which is mainly attributed to the higher clay content. The specific gravity of soil-bentonite mixtures ranges from 2.47 to 2.67 and can be classified as inorganic clays. The liquid limit increases with increase in Bentonite content up to $8 \%$. However, LL of both S-Maira and SCamp soils decreased with increase in bentonite dosage beyond $8 \%$ showing lower capacity of water retention. An increasing trend was observed in plastic limit when more percentage of Bentonite was introduced in M-Zai and SMaira soil whereas decreasing trend can be seen in the case of S-Camp soil. It is found that free swell increases with the percentage addition of Bentonite. The free swell of all soil samples is more than $20 \%$ above $8 \%$ Bentonite substitution; however, a less significant increase is observed beyond $8 \%$ substitution.

It is found that with the percentage addition of Bentonite, MDD decreases and OMC increases. Hydraulic conductivity decreases with the decrease in dry unit weight and increase in optimum moisture content. It is concluded that $8 \%$ Bentonite content by weight yields a suitable mixture for a clay liner that has hydraulic conductivity in the range of recommended limits.

\section{Acknowledgement}

The authors expressed their gratitude to COMSATS University, Abbottabad Campus for providing testing facilities in their laboratories.

\section{Conflicts of Interest}

The authors declare no conflict of interest.

\section{References}

[1] Magsi, A., Environmental Assessment of Solid Waste of Mirpurkhas City \& its Management, in Department of Energy \& Environment Engineering. 2008, Quaid-e-Awam University of Engineering, Science and Technology (QUEST): Nawabshah, Pakistan.

[2] Sánchez-Triana, Ernesto, Santiago Enriquez, Javaid Afzal, Akiko Nakawaga, and Asif Shuja Khan. "Air Pollution in Pakistan." Cleaning Pakistan's Air: Policy Options to Address the Cost of Outdoor Air Pollution (June 26, 2014): 57-81. doi:10.1596/9781-4648-0235-5_ch2.

[3] Jones, D, and N Dixon. "Landfill Lining Stability and Integrity: The Role of Waste Settlement." Geotextiles and Geomembranes 23, no. 1 (February 2005): 27-53. doi:10.1016/j.geotexmem.2004.08.001.

[4] Al Raisi, Sumaiya Abdul Hameed, Hameed Sulaiman, Fakhr Eldin Suliman, and Osman Abdallah. "Assessment of heavy metals in leachate of an unlined landfill in the Sultanate of Oman." International Journal of Environmental Science and Development 5, no. 1 (2014): 60 .

[5] Kerry Rowe, R. "Systems Engineering The Design and Operation of Municipal Solid Waste Landfills To Minimize Contamination of Ground Water." Advances in Environmental Geotechnics (2010): 3-18. doi:10.1007/978-3-642-04460-1_1.

[6] Bostwick, L.E., Laboratory Study Of Geosynthetic Clay Liner Shrinkage When Subjected To Wet/Dry Cycles, in Department of Civil Engineering. 2009, Queen's University: Kingston, Ontario, Canada.

[7] Met, İ., H. Akgün, and A. G. Türkmenoğlu. "Environmental Geological and Geotechnical Investigations Related to the Potential Use of Ankara Clay as a Compacted Landfill Liner Material, Turkey." Environmental Geology 47, no. 2 (September 25, 2004): 225-236. doi:10.1007/s00254-004-1147-4.

[8] Daniel, D.E., Geotechnical Practice for Waste Disposal [electronic resource]. 1993, Boston, MA: Springer US: Imprint: Springer.

[9] Cheng, Tao, Yi Zhang, and Keqin Yan. "Experimental Study of Silty Clay Plane Strain Tri-Axial Test Under RTC Path and Modified Cam-Clay Model.” Civil Engineering Journal 4, no. 3 (April 7, 2018): 518. doi:10.28991/cej-0309112.

[10] Cho, W. J., J. O. Lee, K. S. Chun, and D. S. Hahn. "Basic physicochemical and mechanical properties of domestic bentonite for use as a buffer material in a high-level radioactive waste repository." Journal-Korean Nuclear Society 31, no. 6/SUPP (1999): 39-50.

[11] Memon, Shazim Ali, Rao Arsalan, Sardar Khan, and Tommy Yiu Lo. "Utilization of Pakistani Bentonite as Partial Replacement of Cement in Concrete." Construction and Building Materials 30 (May 2012): 237-242. doi:10.1016/j.conbuildmat.2011.11.021.

[12] Mirza, J., M. Riaz, A. Naseer, F. Rehman, A.N. Khan, and Q. Ali. "Pakistani Bentonite in Mortars and Concrete as Low Cost Construction Material.” Applied Clay Science 45, no. 4 (August 2009): 220-226. doi:10.1016/j.clay.2009.06.011. 
[13] EPA, U.S., Geosynthetic Clay Liners Used in Municipal Solid Waste Landfills, in Solid Waste and Emergency Response. 2001: USA.

[14] Stewart, D.I., P.G. Studds, and T.W. Cousens. "The Factors Controlling the Engineering Properties of Bentonite-Enhanced Sand.” Applied Clay Science 23, no. 1-4 (August 2003): 97-110. doi:10.1016/s0169-1317(03)00092-9.

[15] Dixon, Neil, Edward John Murray, and D. R. V. Jones, eds. Geotechnical Engineering of Landfills: Proceedings of the Symposium Held at the Nottingham Trent University Department of Civil and Structural Engineering on 24 September 1998. Thomas Telford, (1998).

[16] Jo, Won-Jin, Jae-Wan Lee, and Cheol-Hyeong Gang. "Research Papers: Hydraulic Conductivity of Compacted Soil Bentonite Mixture for a Liner Material in Landfill Facilities." Environmental Engineering Research 7, no. 3 (September 30, 2002): 121-127. doi:10.4491/eer.2002.7.3.121.

[17] O'Sullivan, Declan, and Paul Quigley. "Geotechnical engineering and environmental aspects of clay liners for landfill projects." Fehily Timoney \& Co. and Irish Geotechnical Services Ltd. Institution of Engineers of Ireland (2002).

[18] Brown, Teresa Jane, T. Bide, S. D. Hannis, N. E. Idoine, L. E. Hetherington, R. A. Shaw, A. S. Walters, P. A. J. Lusty, and R. Kendall. "World Mineral Production 2004-2008.” British Geological Survey, (2010).

[19] Bagchi, Amalendu. "Design of landfills and integrated solid waste management." John Wiley \& Sons, (2004).

[20] H. Khan, I. and N. Ahsan, Textbook of Solid Wastes Management. (2014): CBS Publisher \& Distributors P Ltd.

[21] Head, Kenneth H., and Roger J. Epps. "Manual of soil laboratory testing.” Vol. 1, no. 2. London: Pentech Press, (1980).

[22] Bell, Fred. Engineering treatment of soils. CRC Press, (1993).

[23] Schmitz, Robrecht M, Christian Schroeder, and Robert Charlier. "Chemo-mechanical Interactions in Clay: a Correlation Between Clay Mineralogy and Atterberg Limits.” Applied Clay Science 26, no. 1-4 (August 2004): 351-358. doi:10.1016/j.clay.2003.12.015.

[24] Tang, Qiang, Takeshi Katsumi, Toru Inui, and Zhenze Li. "Influence of $\mathrm{pH}$ on the Membrane Behavior of Bentonite Amended Fukakusa Clay.” Separation and Purification Technology 141 (February 2015): 132-142. doi:10.1016/j.seppur.2014.11.035.

[25] Das, Braja M. Advanced soil mechanics. CRC Press, (2019).

[26] Al-Khafaji, A. N. "Estimation of Soil Compaction Parameters by Means of Atterberg Limits." Quarterly Journal of Engineering Geology and Hydrogeology 26, no. 4 (November 1993): 359-368. doi:10.1144/gsl.qjegh.1993.026.004.10. 